\title{
Perbedaan estimasi usia kronologis menggunakan metode Moorrees, Fanning dan Hunt modifikasi Smith pada anak laki-laki dan perempuan
}

\author{
Fithrie Rasdiana Makruf ${ }^{1 *}$, Dwi Kartika Apriyono ${ }^{1}$, Supriyadi ${ }^{2}$ \\ ${ }^{1}$ Laboratorium Odontologi Forensik Bagian Biomedik Kedokteran Gigi, Fakultas Kedokteran Gigi \\ Universitas Jember, Indonesia \\ ${ }^{2}$ Instalasi Radiologi Kedokteran Gigi, Fakultas Kedokteran Gigi Universitas Jember, Indonesia
}

*Korespondensi: fithrierasdianamakruf@gmail.com

Submisi: 28 Juli 2021; Penerimaan: 26 Februari 2022; Publikasi Online: 28 Februari 2022

DOI: $10.24198 /$ pjdrrs.v6i1.34848

\begin{abstract}
ABSTRAK
Pendahuluan: Indonesia terletak di pertemuan tiga lempeng tektonik utama di dunia yang merupakan wilayah teritorial yang sangat rawan bencana alam, salah satunya Kabupaten Jember merupakan wilayah rawan bencana ringan hingga sedang. Bencana alam merupakan fenomena alam yang tidak seorangpun mampu memperkirakan kapan terjadinya dan saat terjadinya bencana, kelompok yang paling rentan dalam situasi darurat bencana salah satunya anak sekolah pada fase middle child memiliki kondisi rentan secara psikologis dan sangat bergantung pada pihak-pihak di luar dirinya. Tujuan penelitian ini adalah menganalisis perbedaan estimasi usia kronologis menggunakan metode Moorrees, Fanning dan Hunt modifikasi Smith pada anak laki-laki dan perempuan. Metode: Pengamatan dengan menganalisis setiap citra radiograf panoramik dan penentuan setiap tahapan perkembangan gigi. Estimasi usia gigi ditentukan sesuai dengan tabel usia tahapan perkembangan metode Moorrees, Fanning dan Hunt (MFH) modifikasi Smith. Data hasil penelitian dilakukan analisis statistik menggunakan uji paired t-test. Hasil: Terdapat perbedaan signifikan usia kronologis dengan usia gigi sampel perempuan sebanyak $0,49-0,86$ tahun dengan nilai $p<0,05$ dan terdapat perbedaan signifikan usia kronologis dengan usia gigi sampel laki-laki sebanyak $-0,02-1,19$ tahun dengan nilai $p<0,05$. Simpulan: Terdapat perbedaan estimasi usia kronologis menggunakan metode Moorrees, Fanning dan Hunt modifikasi Smith pada anak laki-laki dan perempuan.
\end{abstract}

Kata kunci: metode Moorrees Fanning Hunt modifikasi Smith; panoramik; anak; usia kronologis

\section{Differences in chronological age estimation with Smith's modified Moorrees, Fanning and Hunt method for male and female children}

\begin{abstract}
Introduction: Indonesia is located at the confluence of three major tectonic plates in the world, a territorial area prone to natural disasters, one of which is Jember Regency, an area prone to mild to moderate disasters. Natural disasters are natural phenomena with a slight chance of prediction. In disaster emergencies, one of the most vulnerable groups is school children in the middle child phase, who are psychologically vulnerable and very dependent. The purpose of this study was to analyse differences in the chronological age estimation with Smith's modified Moorrees, Fanning and Hunt method for male and female children. Methods: Observation by analysing each panoramic radiograph image and determining each stage of tooth development. The estimated tooth age was determined using Smith's modified Moorrees, Fanning and Hunt (MFH) method according to the developmental stage age table. The research data were statistically analysed using the paired t-test. Results: There was a significant difference in chronological age with the dental age of the female children sample $(0.49$ - 0.86 years) with a $p$-value $<0.05$, and there is also a significant difference in chronological age with the dental age of the male children sample (-0.02 - 1.19 years) with a $p$-value $<0.05$. Conclusions: There are differences in estimating chronological age with Smith's modified Moorrees, Fanning and Hunt method for male and female children.
\end{abstract}

Keywords: Smith's modified Moorrees, Fanning, and Hunt method; panoramic; children; chronological age 


\section{PENDAHULUAN}

Indonesia merupakan negara kepulauan yang secara geografis terletak di daerah khatulistiwa, diantara Benua Asia dan Australia serta diantara Samudera Pasifik dan Hindia. Indonesia terletak di pertemuan tiga lempeng tektonik utama di dunia yang merupakan wilayah teritorial yang sangat rawan bencana alam. Kabupaten Jember sendiri merupakan salah satu kabupaten di bagian timur Pulau Jawa yang memiliki tingkat kerawanan bencana yang tinggi. ${ }^{1}$ Permasalahan yang mengakibatkan wilayah Negara Indonesia memiliki potensi rawan bencana baik bencana alam maupun akibat ulah manusia diantaran banjir, gempa bumi, tanah longsor, letusan gunung berapi, tsunami dan kebakaran hutan dan lahan.

Bencana alam merupakan fenomena alam yang tidak seorangpun mampu memperkirakan kapan terjadinya meskipun dengan segala ilmu pengetahuan berusaha untuk memprediksinya dan saat terjadinya bencana, kelompok yang paling rentan dalam situasi darurat bencana diantaranya perempuan terutama remaja perempuan, perempuan hamil, perempuan menyusui, penyandang disabilitas, lanjut usia dan anak-anak. ${ }^{1,2}$ Anak-anak memiliki kemampuan dan sumber daya yang terbatas untuk mengontrol atau mempersiapkan diri ketika merasa takut sehingga sangat bergantung pada pihak-pihak di luar dirinya. ${ }^{3}$

Kerentanan anak-anak terhadap bencana dipicu oleh faktor keterbatasan pemahaman tentang risiko di sekeliling mereka yang mengakibatkan tidak adanya kesiapsiagaan dalam menghadapi bencana. ${ }^{1,3}$ Data kejadian bencana di beberapa daerah menunjukkan banyak korban akibat bencana pada usia anak sekolah baik pada jam sekolah maupun di luar jam sekolah. ${ }^{1}$ Masa anak tengah (middle childhood) pada siswa sekolah dasar memiliki kondisi rentan secara psikologis akibat adanya bencana. ${ }^{4}$

Adanya intensitas yang tinggi untuk terjadinya suatu bencana baik karena faktor alam maupun faktor manusia, diharapkan korban suatu bencana seharusnya dapat diidentifikasi dengan cepat. Tahap pemeriksaan identifikasi ini merupakan tujuan utama untukmembantumengetahuiidentitaskorban.Proses identifikasi juga dapat memberikan ketenangan psikologis bagi keluarga korban yang kemudian dilanjutkan dengan upaya merawat, mendoakan dan menyerahkan kepada pihak keluarga..$^{5}$ Identifikasi forensik merupakan sebuah upaya untuk dapat mengetahui identitas dari seseorang dapat melalui identifikasi korban kejahatan atau bencana masal dengan membandingkan data antemortem (sebelum kematian) dan data postmortem (setelah kematian). ${ }^{6}$ Proses identifikasi ini dilakukan oleh tim Disaster Victim Identification (DVI)

Disaster Victim Identification (DVI) membagi metode tersebut menjadi 5 fase dalam proses identifikasi yang memiliki keterkaitan antara satu dengan yang lain. ${ }^{7}$ Identifikasi korban dapat dilakukan dengan mengidentifikasi gigi geligi namun hal ini membutuhkan data dental record yang akurat dan lengkap sehingga dapat membantu identifikasi menjadi positif identifikasi. ${ }^{8}$ Estimasi usia menggunakan radiografi merupakan salah satu sumber informasi penting di bidang forensik.

Terdapat beberapa metode untuk mengestimasi usia seseorang sebagai tujuan forensik berdasarkan berbagai karakteristik seperti mengamati perkembangan gigi geligi. Penggunaan gigi sebagai indikator dalam menilai dan menentukan umur seseorang dapat dilihat dari aspek morfologis, histologis dan radiografis. ${ }^{9}$ Estimasi usia seseorang menggunakan gigigeligi dapat dilakukan dikarenakan gigi merupakan material biologis yang paling tahan terhadap perubahan lingkungan. ${ }^{10}$

Jaringan pada gigi dilapisi oleh materi anorganik kristal hidroksiapatit sehingga mempunyai daya tahan yang tinggi terhadap suhu serta beragam jenis pengaruh eksternal, iritasi mekanik, dan kimia. ${ }^{11}$ Metode estimasi usia melalui gigi menggunakan metode radiografi dapat mengidentifikasi berbagai hal seperti tahap-tahap kalsifikasi gigi, erupsi dan morfologi gigi. Pertumbuhan dan perkembangan gigi merupakan suatu rangkaian kompleks dari mineralisasi awal, pembentukan mahkota, dan pertumbuhan akar dan dapat dengan mudah divisualisasikan pada radiografi. ${ }^{12}$

Teknik radiografi adalah metode sederhana yang dapat digunakan pada individu hidup atau mati dengan berbagai teknik radiografi yang dapat digunakan seperti radiografi intraoral periapikal, lateral oblique, sefalometrik, dan panoramik. ${ }^{13}$ Metode Moorrees, Fanning dan Hunt modifikasi Smith merupakan salah satu metode radiografi yang dapat digunakan untuk individu dengan kisaran usia 0,6 tahun hingga 19,5 tahun untuk jenis kelamin lakilaki dan perempuan. ${ }^{14}$ Metode ini merupakan metode yang dicirikan dengan tiga belas tahap perkembangan 
gigi untuk gigi berakar tunggal dan empat belas tahap perkembangan gigi untuk gigi berakar ganda. ${ }^{14,15,16}$ Setiap tahap perkembangan memiliki nilai numerik khusus untuk gigi yang dievaluasi kemudian nilai tersebut direratakan untuk memperkirakan usia gigi individu. Usia gigi adalah usia dimana rerata anak dalam kelompok tertentu menunjukkan sejauh apa tahap dari mineralisasi gigi. ${ }^{16}$

Penelitian dengan menggunakan Metode Moorrees, Fanning dan Hunt modifikasi Smith belum pernah dilakukan di Indonesia khususnya di Kabupaten Jember, metode ini dapat digunakan sebagai pengembangan dan metode pendukung untuk metode radiografi lainnya seperti Metode Nolla dan Metode Demirjian untuk dapat meningkatkan dan sebagai hasil banding dalam membantu meningkatkan derajat validasinya untuk proses identifikasi korban bencana di Indonesia. Tujuan penelitian menganalisis perbedaan estimasi usia kronologis menggunakan metode Moorrees, Fanning dan Hunt modifikasi Smith pada anak laki-laki dan perempuan

\section{METODE}

Hasil pengamatan dan analisis setiap gambaran radiograf gigi geligi serta penentuan setiap tahapan perkembangan gigi, estimasi usia masing-masing gigi ditentukan sesuai dengan tabel usia rerata tahapan perkembangan baik untuk laki-laki dan perempuan sesuai metode Moorrees, Fanning dan Hunt modifikasi Smith. ${ }^{15,17}$ Estimasi setiap usia yang didapat dari metode Moorres, Fanning, dan Hunt modifikasi Smith, dihitung mean dan kemudian dibandingkan dengan usia pasien dari data medis dengan menghitung usia pasien dimulai sejak tanggal lahir pasien sampai dengan tanggal dilakukannya radiograf panoramik dengan satuan hari yang kemudian dikonfersikan ke satuan tahun (satu tahu setara 365 hari).

Data hasil penelitian yang didapat selanjutnya dilakukan uji normalitas menggunakan Kolmogorov Smirnov. Data menunjukkan berdistribusi normal sehingga dilakukan uji statistik parametrik dengan uji Paired T-test untuk melihat perbedaan antara dua kelompok sampel. Penelitian ini telah disetujui oleh Komisi Etik Penelitian Fakultas Kedokteran Gigi Universitas Jember No. 1181/ UN25.8/ KEPK/ DL/ 2021

\section{HASIL}

Penelitian estimasi usia kronologis anak-anak di Kabupaten Jember melalui pengamatan gigi menggunakan metode Moorrees, Fanning, dan Hunt modifikasi Smith dengan sampel sebesar 86 sampel radiograf panoramik digital dari jenis kelamin lakilaki 41 dan perempuan berjumlah 45 sampel.

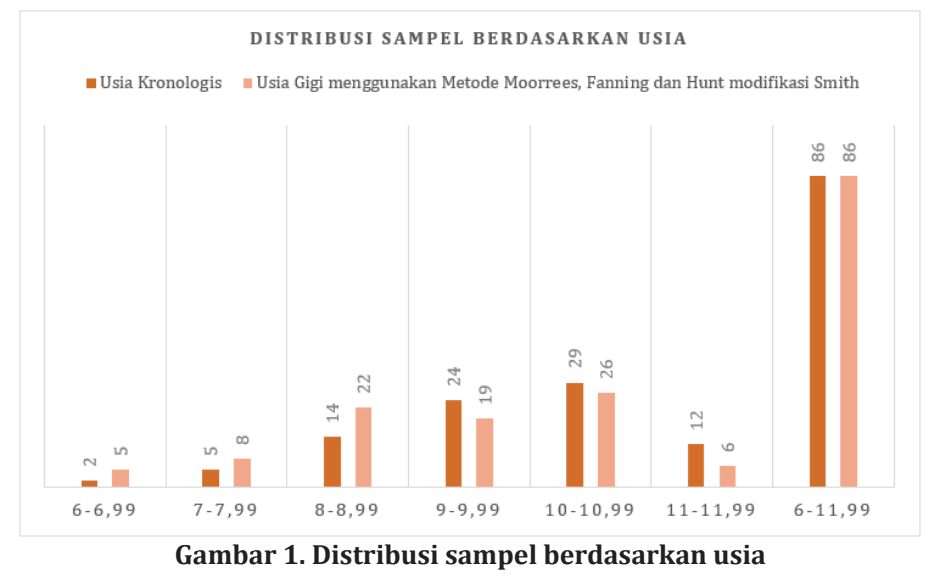

Radiograf panoramik menurut usia kronologis pasien dengan total 86 radiograf terdiri dari radiograf digital panoramik dari pasien anak usia 6 sampai 11 tahun; 2 radiograf dari pasien usia 6 tahun, 5 radiograf dari pasien usia 7 tahun, 14 radiograf dari pasien usia 8 tahun, 24 radiograf dari pasien usia 9 tahun, 29 radiograf dari pasien usia 10 tahun, 12 radiograf dari pasien usia 11 tahun. Menurut usia gigi pasien berdasarkan metode Moorrees, Fanning dan Hunt modifikasi Smith terdiri dari radiograf digital panoramik dari pasien anak usia 6 sampai 11 tahun; 5 radiograf dari pasien usia 6 tahun, 8 radiograf dari pasien usia 7 tahun, 22 radiograf dari pasien usia 8 tahun, 19 radiograf dari pasien usia 9 
tahun, 26 radiograf dari pasien usia 10 tahun, dan 6 radiograf dari pasien usia 11 tahun. Berdasarkan data penelitian, hasil analisis data uji normalitas menggunakan Kolmogorov-Smirnov menunjukkan sig. $>0,05$ yaitu nilai signifikansi $0,132>0,05$ pada kelompok sampel perempuan dan menunjukkan sig. $>0,05$ yaitu nilai signifikansi $0,200>0,05$ pada kelompok sampel laki-laki sehingga dapat membuktikan bahwa data terdistribusi normal. Data penelitian yang sudah di uji memenuhi uji normalitas, dilakukan uji Paired T-test. Paired T-test digunakan untuk menguji signifikansi data perbedaan nilai rerata dari usia sampel dan usia gigi berdasarkan metode Morreess, Fanning, dan Hunt modifikasi Smith. Hasil uji Paired T-test didapatkan hasil seperti pada tabel 1:

Tabel 1. Hasil uji Paired T-test antara usia kronologis dan usia gigi pada anak perempuan menggunakan standar Morreess, Fanning dan Hunt modifikasi Smith

\begin{tabular}{cccccr}
\hline \multicolumn{2}{c}{ Kelompok Usia } & \multicolumn{5}{c}{ Rerata ( \pm ) SD } & Nilai p \\
\cline { 1 - 4 } Kategori (ahun) & $\mathbf{N}$ & Usia kronologis (tahun) & Usia gigi (tahun) & Perbedaan usia (tahun) & - \\
\hline $6-6,99$ & - & - & - & - & 0,124 \\
$7-7,99$ & 2 & $7,35(0,16)$ & $6,63(0,04)$ & $0,72(0,20)$ & 0,042 \\
$8-8,99$ & 6 & $8,76(0,34)$ & $8,03(0,73)$ & $0,73(0,66)$ & 0,004 \\
$9-9,99$ & 15 & $9,51(0,20)$ & $8,97(0,69)$ & $0,54(0,60)$ & 0,001 \\
$10-10,99$ & 14 & $10,49(0,28)$ & $9,996(0,50)$ & $0,49(0,44)$ & 0,079 \\
$11-11,99$ & 8 & $11,46(0,32)$ & $10,6(1,07)$ & $0,86(1,18)$ & 0,001 \\
$6-11,99$ & 45 & $9,97(-0,08)$ & $9,35(0,38)$ & $0,61(0,36)$ &
\end{tabular}

6-6,99: Kelompok usia sampel 6-6,99 tahun., 7-7,99: Kelompok usia sampel 7-7,99 tahun., 8-8,99: Kelompok usia sampel 8-8,99 tahun., 9-9,99 : Kelompok usia sampel 9-9,99 tahun., 10-10,99: Kelompok usia sampel 10-10,99 tahun., 11-11,99 : Kelompok usia sampel 11-11,99 tahun., 6-11,99 : Kelompok usia sampel 6-11,99 tahun., $n$ : total sampel., Nilai p : Nilai uji Paired $T$ test

Berdasarkan data penelitian, hasil analisis data menggunakan uji Paired $T$ test (Tabel 1) menunjukkan nilai signifikansi dari 4 kategori yaitu kategori 8-8,99; kategori 9-9,99; kategori 10-10,99; kategori 6-11,99 kurang dari nilai $\alpha 5 \%(0,05)(\mathrm{p}<$ $0,05)$ sehingga diartikan bahwa terdapat perbedaan antara usia sampel dengan usia gigi berdasarkan metode Morreess, Fanning dan Hunt modifikasi
Smith sedangkan 2 kategori lainnya yaitu kategori 7-7,99 dan kategori 11-11,99 menunjukkan nilai signifikansi yaitu lebih dari nilai $\alpha 5 \%(0,05)(\mathrm{p}$ $>0,05)$ sehingga diartikan bahwa tidak terdapat perbedaan antara usia sampel dengan usia gigi berdasarkan metode Morreess, Fanning dan Hunt modifikasi Smith. Berdasarkan data penelitian, hasil analisis data menggunakan uji Paired T test (Tabel2)

Tabel 2. Hasil uji Paired T-test antara usia kronologis dan usia gigi pada anak laki-laki menggunakan standar Morreess, Fanning dan Hunt modifikasi Smith

\begin{tabular}{|c|c|c|c|c|c|}
\hline \multicolumn{2}{|c|}{ Kelompok Usia } & \multicolumn{3}{|c|}{ Rerata ( \pm ) SD } & \multirow{2}{*}{ Nilai p } \\
\hline Kategori (tahun) & $\mathbf{N}$ & Usia Kronologis (tahun) & Usia Gigi (tahun) & Perbedaan Usia (tahun) & \\
\hline $6-6,99$ & 2 & $6,96(0,03)$ & $6,98(0,43)$ & $-0,02(0,47)$ & 0,967 \\
\hline $7-7,99$ & 3 & $7,47(0,40)$ & $7,09(0,34)$ & $0,38(0,06)$ & 0,010 \\
\hline $8-8,99$ & 8 & $8,70(0,22)$ & $8,42(0,75)$ & $0,28(0,79)$ & 0,350 \\
\hline $9-9,99$ & 9 & $9,54(0,31)$ & $9,10(0,61)$ & $0,44(0,51)$ & 0,033 \\
\hline $10-10,99$ & 15 & $10,48(0,25)$ & $10,18(0,72)$ & $0,30(0,55)$ & 0,055 \\
\hline $11-11,99$ & 4 & $11,50(0,22)$ & $10,31(0,88)$ & $1,19(1,04)$ & 0,107 \\
\hline $6-11,99$ & 41 & $9,63(0,12)$ & $9,23(0,20)$ & $0,40(0,33)$ & 0,000 \\
\hline
\end{tabular}

6-6,99 : Kelompok usia sampel 6-6,99 tahun., 7-7,99: Kelompok usia sampel 7-7,99 tahun., 8-8,99 : Kelompok usia sampel 8-8,99 tahun., 9-9,99 : Kelompok usia sampel 9-9,99 tahun., 10-10,99: Kelompok usia sampel 10-10,99 tahun., 11-11,99 : Kelompok usia sampel 11-11,99 tahun., 6-11,99 : Kelompok usia sampel 6-11,99 tahun., n : total sampel., Nilai p : Nilai uji Paired T test 
menunjukkan nilai signifikansi dari 3 kategori yaitu kategori 7-7,99; kategori 9-9,99; kategori 6-11,99 kurang dari nilai $\alpha 5 \%(0,05)(\mathrm{p}<0,05)$ sehingga diartikan bahwa terdapat perbedaan antara usia sampel dengan usia gigi berdasarkan metode Morreess, Fanning dan Hunt modifikasi Smith sedangkan 4 kategori lainnya yaitu kategori 6-6,99; kategori 8-8,99; kategori 10-10,99; kategori 1111,99 menunjukkan nilai signifikansi yaitu lebih dari nilai $\alpha 5 \%(0,05)(\mathrm{p}>0,05)$ sehingga diartikan bahwa tidak terdapat perbedaan antara usia sampel dengan usia gigi berdasarkan metode Morreess, Fanning dan Hunt modifikasi Smith.

\section{PEMBAHASAN}

Penelitian ini merupakan penelitian observasional deskriptif dengan desain cross sectional dengan metode pengambilan data secara retrospektif menggunakan data sekunder. Pengamatan penelitian menggunakan sampel radiograf panoramik digital yang ada di Instalasi Radiologi Kedokteran Gigi Rumah Sakit Gigi dan Mulut Universitas Jember dengan metode Moorrees, Fanning dan Hunt modifikasi Smith. Metode Moorrees, Fanning dan Hunt modifikasi Smith merupakan metode yang diusulkan oleh Moorrees, Fanning dan Hunt dan kemudian dimodifikasi oleh Smith tetapi dengan data yang telah dikerjakan ulang dengan perbedaan yang penting. ${ }^{15,17}$ Perbedaan tersebut adalah nilai pada tabel yang telah dikerjakan ulang untuk menunjukkan usia di suatu tahap yang mewakili titik tengah antara satu tahapan (tahapan awal) ke tahap berikutnya. Tabel tersebut menunjukkan usia dimana transisi dari satu tahap ke tahap perkembangan berikutnya terjadi. ${ }^{16}$

Metode Moorrees, Fanning dan Hunt modifikasi Smith digunakan untuk sampel dengan kisaran usia 0,6 tahun hingga 19,5 tahun dengan mengamati tiga belas tahap perkembangan gigi sesuai dengan representasi grafis yang dipublikasikan. ${ }^{15,17}$ Metode Moorrees, Fanning dan Hunt modifikasi Smith dicirikan dengan terdapat tiga belas tahap perkembangan dan tahap bifurkasi akar yang terdapat pada molar yang dikelompokkan menjadi tiga tahap perkembangan yaitu pembentukan mahkota, pembentukan akar dan penutupan apikal. ${ }^{16}$

Tiga tahap utama yang diamati berawal dari pembentukan mahkota yang diawali tahap Ci (Cusp Initiation) yang merupakan pembentukan awal dari cusp sampai akhirnya di tahap Crc (Crown Completed Formed) yaitu mahkota terbentuk sempurna. Kemudian tahap pembentukan akar diawali tahap Ri (Root Initiation) sampai pada tahap Rc (Root Complete). Kemudian tahap penutupan apikal, pada tahap ini hanya memiliki dua tahap yaitu tahap A1 12 (Apex One Half Complete) dan Ac (Apex Complete)..$^{15,16,18}$ Saat metode Moorrees, Fanning dan Hunt diterapksan, kisaran kesalahan yang diperkirakan dalam penentuan usia kronologis antar populasi dapat sangat bervariasi. ${ }^{14}$ Hasil dari penelitian ini terlihat adanya perbedaan antara keduanya. Ketika Moorrees, Fanning dan Hunt diterapkan untuk penelitian ini, ditemukan bahwa metode ini cenderung menghasilkan nilai yang lebih rendah. Hal ini tidak sesuai dengan sebuah studi oleh duran et $a l^{15}$, pada tahun 2015 dalam memprediksi usia kronologis pasien anak yang dirawat di Fakultas Odontologi, Universitas Yucatan dan penelitian oleh Corral Cols pada tahun 2010.

Hasil penelitian ini didapatkan nilai estimasi usia yang menghasilkan nilai lebih tinggi. Penelitian pada sampel perempuan menghasilkan perbedaan usia dengan nilai yang lebih rendah serta bervariasi namun tidak lebih dari satu tahun dengan mempunyai perbedaan usia 0,49-0,86 tahun dengan diperoleh rerata perbedaan usia mencapai 0,66 tahun lamanya. Sampel laki-laki terlihat satu kategori berjumlah 2 sampel yang memiliki perbedaan usia -0,02 tahun. Sampel lainnya mempunyai perbedaan usia yang bervariasi dengan perbedaan usia $0,28-0,40$ tahun dan terdapat sampel memiliki rerata perbedaan usia hingga sebesar 1,19 tahun. Sampel lainnya mempunyai perbedaan usia yang bervariasi dengan perbedaan usia 0,28-0,40 tahun dan terdapat sampel memiliki rerata perbedaan usia hingga sebesar 1,19 tahun.

Rerata perbedaan usia sampel laki-laki mencapai 0,42 tahun lamanya. Perbedaan persentase keberhasilan diperkirakan dapat disebabkan oleh jumlah gigi. Jumlah gigi yang lebih sedikit pada periode mineralisasi menghasilkan pada usia awal presisi lebih besar karena jumlah gigi yang terbentuk lebih banyak dan tahapan morfologi lebih pendek. ${ }^{14}$ Hal ini tidak selaras dengan hasil penelitian Cardona et $a{ }^{17}$. Tahun 2019 yang menyatakan bahwa metode ini dapat diterapkan secara efektif baik untuk laki-laki dan perempuan. ${ }^{18}$ Metode Morrees, Fanning dan Hunt modifikasi Smith diterapkan untuk memperkirakan usia gigi dalam penelitian ini, ditemukan bahwa 
metode tersebut cenderung menghasilkan nilai yang lebih rendah, dan hal ini selaras dengan penelitiannya Rodríguez Belia pada populasi Meksiko dengan 210 radiografi panoramik. ${ }^{19}$ Hasil dari penelitian ini dengan menggunakan metode Moorrees, Fanning dan Hunt modifikasi Smith terlihat bahwa baik pada anak perempuan dan anak laki-laki data berdistribusi normal. Hasil data tersebut menunjukkan bahwa data tersebut saling berkorelasi atau berhubungan yaitu menunjukkan korelasi yang tinggi berkaitan dengan usia kronologis.

\section{SIMPULAN}

Terdapat perbedaan estimasi usia kronologis menggunakan metode Moorrees, Fanning dan Hunt modifikasi Smith pada anak laki-laki dan perempuan.

\section{DAFTAR PUSTAKA}

1. Permata Sari Vanny dkk. Desain Prototype Aplikasi Pencatatan Korban Bencana Pendukung Mitigasi Bencana di Kabupaten Jember. J Rek Med Inform Kes. 2020; 1(3): 281-7. DOI: 10.25047/ jremi.v1i3.2069

2. Pahleviannur MR. Edukasi sadar bencana melalui sosialisasi kebencanaan sebagai upaya peningkatan pengetahuan siswa terhadap mitigasi bencana. J Pend Ilmu Sos (JPIS). 2019; 29(1): 49-55. DOI: 10.23917/jpis.v29i1.8203

3. Teja, Mohammad. Kesiapsiagaan Masyarakat Terhadap Kelompok Rentan Dalam Menghadapi Bencana Alam di Lombok. Pusat Penelitian Badan Keahlian DPR RI. 2018; 10(17).

4. Herdwiyanti F, Sudaryono. Perbedaaan Kesiapsiagaan Menghadapi Bencana Ditinjau Dari Tingkat Self-Efficacy pada Anak Usia Sekolah Dasar di Daerah Dampak Bencana Gunung Kelud. J Psikologi Kep Sos. 2013; 2(1): 136-141.

5. Dariyo A. Dasar-dasar Pedadogi Modern.[home page on internet]. Jakarta: Indeks. 2013: h. 54-7

6. Apriyono, Dwi K. Metode Penentuan Usia Melalui Gigi dalam Proses Identifikasi Korban. CDK-236. 2016; 43(1). DOI: 10.55175/cdk.v43i1.14

7. Tandaju Cornelius F, James Siwu, Bernart S. P. Hutagalung. Gambaran pemeriksaan gigi untuk identifikasi korban meninggal di bagian kedokteran forensik dan medikolegal rsup prof. Dr. R. D. Kandou manado tahun 2010 - 2015. J e-GiGi (eG). 2017; 5(1): 96-99. DOI: 10.35790/ eg.5.1.2017.15534

8. Setyawan, Erwin, Dimas Setiyanto, Latifa Wahyudi Putri. Perbandingan keakuratan penentuan usia antara metode demirjian, cameriere, dan blenkin-taylor. Insisiva Dent J: Maj Ked Gig Insisiva. 2021; 10(2): 58-64. DOI: 10.18196/di.v10i2.12972

9. Novita, Masniari, Waloejo Noergroho. Pembuatan Dental Record yang Baik: Identifikasi Imigran Korban Kapan Tenggelam di Trenggalek 2011. Stomatognatic (J.K.G. Unej). 2013; 10(2): 51-53.

10. Chandramala R, Sharma R, Khan M, Srivastava A. Application of kvaal's technique of age estimation on digital panoramic radiographs. Dentistry. 2012; 2: 142-7

11. Apriyono, Dwi K. Prakiraan Usia Gigi Menggunakan Standar Blenkin (Modifikasi Metode Demirjian) pada Anak-Anak Etnik Jawa di Kabupaten Jember. Stomatognatic (J.K.G. Unej). 2020; 17(2): 60-6. DOI: 10.19184/stoma. v17i2.25221

12. Garg Y, Bhaskar DJ, Agali CR, Garg K. Forensic Dentistry: An Aid in Criminal Investigation. Int ] Dent Med Res 2015; 1(6): 160-3. DOI:

13. Liversidge, H. M. The assessment and interpretation of Demirjian, Goldstein and Tanner's dental maturity. Annals of Human Biology. 2012; 39(5): 412-431. DOI: 10.3109/03014460.2012.716080.

14. Auliyah NI. Estimasi usia berdasarkan gambaran gigi radiografi panoramik pada metode harris dan nortje. [Skripsi]. Makassar: FKG Unhas; 2016. h.1-60.

15. Duran, Ricalde, Rodriguez CB, Pinzon TA, Perez TLB, Gonzales SP. Precisión del método de Moorrees en la predicción de la edad cronológica en pacientes pediátricos. Rev Odontol Latinoam. 2015; 7(2): 47-51.

16. Smith BH. Standards of human tooth formation and dental age assessment. In: Advances in Dental Anthropology, New York: Wiley-Liss. 1991; pp.143-168.

17. Skanchy TL, Maness H, Al Dayeh A, Haris EF. A Comparison of Two Dental Age Estimation Techniques in Contemporary American Whites: The Moorrees and Demirjian Approaches. Internasional J Forensic Science and Pathology (IJFP). 2016; 4(5): 243-248

18. Cardona JKA. Aplicación del método de Moorrees, Fanning y Hunt modificado por Smith 
(1991) para predecir la edad cronológica en subadultos con fines antropológicos y forenses. Revista Científica del SEP. 2019; 2: 52-67. DOI: 10.36958/sep.v2i01.19
19. Rodriguez BI, Cucina A. Maduracion y erupcion dental. Manual de Antropología Dental. Mexico: Universidad Autonoma de Yucatan; 2011; 3:5174 